\title{
Microwave assisted bi-functional activation of $\beta$-bromo-tert-alcohols
}

\author{
NANDINI KANNAN, MANJUNATHA JAVAGAL RANGASWAMY and \\ BETTADAIAH BHEEMANAKERE KEMAPAIAH* (D) \\ Spice and Flavour Science Department, CSIR-Central Food Technological Research Institute, \\ Mysore 570 020, India \\ e-mail: bettadaiah@cftri.res.in
}

MS received 19 September 2014; revised 5 May 2015; accepted 10 May 2015

\begin{abstract}
Microwave-assisted dehydration-oxidation of $\beta$-bromo-tert-alcohols to afford 2,3-unsaturated ketones in good yield is reported. The reaction of substrates with DMSO in 1:1 ratio (w/v) is promoted by $\mathrm{ZnS}$ in a solvent-free condition. A concurrent bi-functional activation of trans-vicinal bromo- and hydroxyl groups with $\mathrm{ZnS}$ is elucidated. This is a new observation under microwave and applies to $\beta$-bromo-tert-alcohols derived from 1,4-disubstitued-1-cyclohexenes. It is very useful in the synthesis of 2,3-unsaturated ketones derived from monoterpenes which are valuable flavour compounds.
\end{abstract}

Keywords. $\quad \beta$-Bromo-tert-alcohols; microwave; bi-functional activation; $\mathrm{ZnS}$; flavour compounds.

\section{Introduction}

Microwave-assisted organic synthesis provides a solventless, fast-access and very clean approach for the synthesis of valuable chemicals. It is also beneficial over conventional reactions in affording high product yield. ${ }^{1-4}$ The green procedures in the chemical synthesis of flavour are scarce and hence it attracts the chemists to adopt microwave-assisted synthesis in this field. $\beta$-Bromo-tert-alcohols are the products of functionalization of olefins by a process called co-halogenation. ${ }^{5}$ They are very important intermediates for introduction of various functionalities regio- and stereo-specifically. These intermediates are of prime focus for various conversions such as direct transformation of $\beta$-bromoalcohols to carbonyl compounds by irradiation in benzene/ toluene. This reaction proceeds through radical elimination of $\mathrm{HBr}$ leading to formation of ketones ${ }^{6,7}$ A facile bromination of porphyrin using NBS to prepare $\beta$ ferrocenyl porphyrins and their structural, photophysical and electrochemical properties is reported. ${ }^{8}$ Direct conversion of $\beta$-bromo-tert-alcohols to ketones of flavour interest and their dehydration to stereo-specific allylic bromides is reported. ${ }^{9,10}$ The direct oxidation using $\mathrm{ZnS} / \mathrm{DMSO}$ is limited due to slow reaction and also due to use of DMSO as a solvent. The $\beta$-bromo-tertalcohol derived from $R$-limonene is the intermediate in the stereo-specific synthesis of trans- $\beta$-terpineol. ${ }^{11}$

In the present work, oxidation of $\beta$-bromo-tertalcohols, such as $\mathbf{1}$ using DMSO in presence of $\mathrm{ZnS}$

\footnotetext{
*For correspondence
}

under microwave irradiation was explored (scheme 1). We observed the formation of 2,3-unsaturated ketone (1a) as a major product by dehydration-oxidation. It is a new observation where direct dehydration-oxidation in one-pot taking place under microwave irradiation. It was also found that the amount of DMSO used in the reaction was not a critical factor, since 1a was formed to an equal extent in either case wherein DMSO as a solvent or as an oxidant in 1:1 ratio with the substrate. Hence, it is solvent-less, one-pot direct dehydrationoxidation of $\beta$-bromo-tert-alcohol to unsaturated ketone. We are interested in extending the scope of this protocol for a range of $\beta$-bromo-tert-alcohols derived from monoterpenes which are important flavour chemicals (1-5, figure 1).

\section{Experimental}

\subsection{General}

Laboratory grade solvents were generally used. Petroleum ether refers to $60-80^{\circ} \mathrm{C}$ boiling fraction. Pre-coated aluminium silica $60 \mathrm{~F}_{254}$ plates from Merck were used for TLC analyses. Column chromatography was performed using silica gel 200-400 mesh using petroleum ether and ethyl acetate mixture. All reactions were performed in a microwave reactor (Milestone lab station, model Start S, Italy). NMR spectra were recorded on $500 \mathrm{MHz}$ NMR spectrometer (Bruker Avance, Reinstetten, Germany) using $\mathrm{CDCl}_{3}$ solvent. The chemical shift values reported with reference to signals at $7.26 \mathrm{ppm}$ 


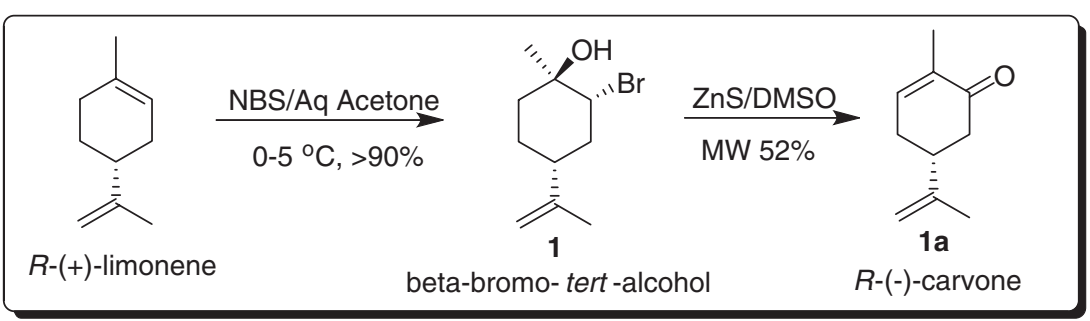

Scheme 1. Microwave-assisted synthesis of $R$-(-)-carvone.

$\left(\mathrm{CHCl}_{3}\right.$ for $\left.{ }^{1} \mathrm{H}\right)$ and $77.16 \mathrm{ppm}\left(\mathrm{CDCl}_{3}\right.$ for $\left.{ }^{13} \mathrm{C}\right)$. GCMS of all the compounds were recorded on a Perkin-Elmer Auto System XL gas chromatograph coupled to TurboMass Gold mass spectrometer having a quadrupole mass analyzer. The mass spectrometer was operated at an ionization potential of $70 \mathrm{eV}$ in electron-impact ionization (EI) scan mode with mass range set between 40 to $400 \mathrm{amu}$. The IR spectra ( $\mathrm{KBr}$ pellets) were recorded on a FT Raman-Nicolet 5700 instrument. NBS used was purified by recrystallization in hot water. Pure (+)limonene was obtained from cold pressed orange oil by fractional distillation under reduced pressure. It was hydrogenated using Raney Nickel catalyst in ethanol at $2 \mathrm{~atm}$ pressure to get (+)-p-menthane. (-)- Limonene was purchased from Sigma-Aldrich Chemicals Ltd and it was hydrogenated using Raney Nickel as catalyst in ethanol at $2 \mathrm{~atm}$ pressure to afford (-)- $p$-menthane. $\alpha$ Terpineol was purchased from Aldrich Chemicals Ltd and used as received.

\subsection{Preparation of $\beta$-bromo-tert-alcohols with General Structures 1-5}

In a flask, olefin and NBS (1:1.2) were mixed with $15 \%$ aqueous acetone and allowed for stirring until completion of reaction by TLC. Upon completion of reaction, acetone was removed by flash evaporation and diluted with water. Extraction with DCM (3 times) and its concentration afforded crude product, which was purified by column chromatography. The pure compounds were characterised by spectral studies and compared with those from literature in case of $\mathbf{1}$ and $2 .{ }^{9}$

2.2a (1S,2S,4R)-2-Bromo-1-hydroxy-p-menth-8-ene (1): Compound 1 was prepared from limonene $(5.0 \mathrm{~g}$, $36.8 \mathrm{mmol}$ ) and NBS (7.85 g, $44.10 \mathrm{mmol})$ in $15 \%$ aqueous acetone $(50 \mathrm{~mL})$. Column chromatographic purification (eluent, 2\% EtOAc in petroleum ether) followed by distillation under reduced pressure (B.p. $85-87^{\circ} \mathrm{C} / 0.5$ torr $)^{9}$ resulted in colourless liquid, yield $85 \%$ (7.26 g, $31.3 \mathrm{mmol})$.

\section{$2.2 \mathrm{~b} \quad(1 S, 2 S, 4 R)-2-B r o m o-1-h y d r o x y-p-m e n t h a n e(2)$ :} Compound 2 was prepared from $(+)$ - $p$-menthane (5.0 $\mathrm{g}, 36.2 \mathrm{mmol}$ ) and NBS (7.74 g, $44.50 \mathrm{mmol})$ in aqueous acetone $(50 \mathrm{~mL})$. Column chromatographic purification (eluent, 2\% EtoAc in petroleum ether) followed by distillation under reduced pressure (B.p. $97-99^{\circ} \mathrm{C} / 1$ torr $)^{9}$ resulted in colourless liquid, yield $90 \%$ (7.62 g, $32.6 \mathrm{mmol})$.

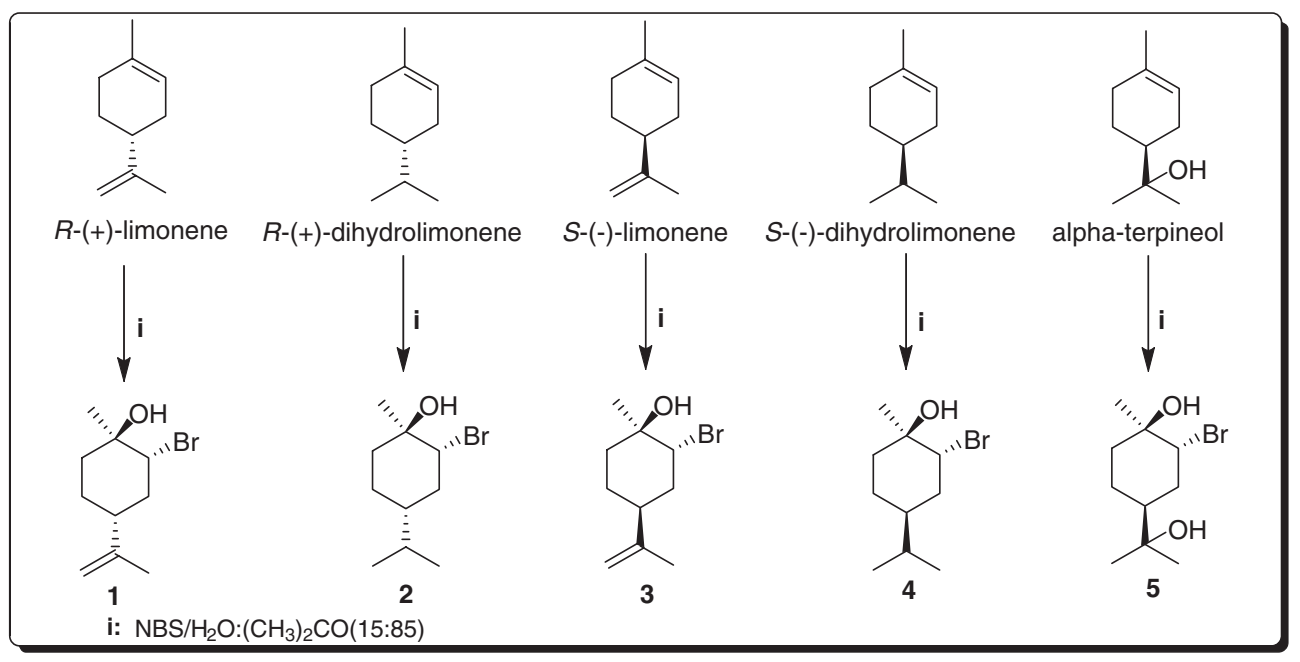

Figure 1. Structure of $\beta$-bromo-tert-alcohols derived from limonene, dihydrolimonene and $\alpha$-terpineol. 
2.2c (1R,2S,4S)-2-Bromo-1-hydroxy-p-menth-8-ene (3): Compound 3 was prepared from (-)-Limonene $(5.0 \mathrm{~g}$, $36.8 \mathrm{mmol})$ and NBS $(7.85 \mathrm{~g}, 44.10 \mathrm{mmol})$ in aqueous acetone $(50 \mathrm{~mL})$. Column chromatographic purification (eluent, 2\% EtOAc in petroleum ether) followed by distillation under reduced pressure (B.p. $86-88^{\circ} \mathrm{C} / 0.5$ torr) resulted in colourless liquid with yield $92 \%$ (7.85 g, $33.86 \mathrm{mmol})$. The product was authenticated by NMR spectral studies and confirmed by HRMS.

${ }^{1} \mathrm{H}$ NMR $\left(500 \mathrm{MHz}, \mathrm{CDCl}_{3}\right): 1.45\left(\mathrm{~s}, 7-\mathrm{CH}_{3}, 3 \mathrm{H}\right)$, 1.59-1.62 (m, 5- $\left.\mathrm{CH}_{2}, 1 \mathrm{H}\right), 1.63-1.68\left(\mathrm{~m}, 0.55-\mathrm{CH}_{2}\right.$, $\left.0.53-\mathrm{CH}_{2}, 2 \mathrm{H}\right) 1.76\left(\mathrm{~s}, 10-\mathrm{CH}_{3}, 3 \mathrm{H}\right), 1.96-2.06(\mathrm{~m}$, $0.53-\mathrm{CH}_{2}, 0.56-\mathrm{CH}_{2}, 2 \mathrm{H}$ ), 2.29 (ddd, $J=14.5,11.0$, $3.2 \mathrm{~Hz}, 0.5$ 6- $\mathrm{CH}_{2}, 1 \mathrm{H}$ ), 4.22 (b s, 2-CHBr, $1 \mathrm{H}$ ), 4.77 $\left(\mathrm{d}, J=12.13 \mathrm{~Hz}, 9-\mathrm{CH}_{2}, 2 \mathrm{H}\right) .{ }^{13} \mathrm{C} \mathrm{NMR}(125 \mathrm{MHz}$, $\mathrm{CDCl}_{3}$ ): 21.3 (C-10), 26.1 (C-5), 29.4 (C-7), 33.2 (C3), 35.7 (C-6), 38.4 (C-4), 60.1 (C-2), 71.7 (C-1), 109.5 (C-9), 148 (C-8). HRMS (ESI-TOF): $[\mathrm{M}+\mathrm{H}]^{+}$Calcd for $\mathrm{C}_{10} \mathrm{H}_{18} \mathrm{BrO}$ : 233.0541; Found: 233.0562. GC-MS $(m / z):$ 232(1), 234(1), 217(2), 214(5), 153(2), 135(70), 108(36), 95(13), 93(45), 71(100), 43(75). IR (neat): 2938(s), 3083(s), 3411(broad, s) $\mathrm{cm}^{-1}$.

$$
[\alpha]_{\mathrm{D}}^{20}=-51.14^{\circ}\left(c=0.33, \mathrm{CH}_{3} \mathrm{OH}\right) .
$$

2.2d (1R, 2S, 4S)-2-Bromo-1-hydroxy-p-menthane (4): Compound 4 was prepared from (-)- $p$-menthane $(5.0 \mathrm{~g}, 36.2 \mathrm{mmol})$ and NBS (7.74 g, $44.50 \mathrm{mmol})$ in aqueous acetone. Column chromatographic purification (eluent, 2\% EtOAc in petroleum ether) resulted in colourless liquid, yield 82\% (6.95 g, $29.7 \mathrm{mmol})$. The product was authenticated by NMR spectral studies and confirmed by HRMS.

${ }^{1} \mathrm{H}$ NMR (500 MHz, $\left.\mathrm{CDCl}_{3}\right): 0.87(\mathrm{~d}, J=2 \mathrm{~Hz}, 9-$ $\left.\mathrm{CH}_{3}, 3 \mathrm{H}\right), 0.89\left(\mathrm{~d}, J=2.14 \mathrm{~Hz}, 10-\mathrm{CH}_{3}, 3 \mathrm{H}\right), 1.40$ (s, 7- $\left.\mathrm{CH}_{3}, 3 \mathrm{H}\right), 1.42-1.48$ (m, 8-CH, $\left.1 \mathrm{H}\right), 1.49-1.54$ (m, $\left.0.55-\mathrm{CH}_{2}, 0.56-\mathrm{CH}_{2}, 2 \mathrm{H}\right), 1.55-1.62(\mathrm{~m}, 0.5$ 5$\mathrm{CH}_{2}, 0.5$ 4-CH, $2 \mathrm{H}$ ), 1.88-1.93 (m, $\left.0.53-\mathrm{CH}_{2}, 1 \mathrm{H}\right)$, 1.94-1.98 (m, 0.5 6- $\left.\mathrm{CH}_{2}, 1 \mathrm{H}\right), 2.03-2.08(\mathrm{~m}, 0.5$ 3$\left.\mathrm{CH}_{2}, 1 \mathrm{H}\right), 4.18-4.19$ (broad s, 2-CHBr, $\left.1 \mathrm{H}\right) .{ }^{13} \mathrm{C}$ NMR (125 MHz, $\mathrm{CDCl}_{3}$ ): 19.6 (C-10), 19.8 (C-9), 23.9 (C-5), 28.9 (C-8), 30.8 (C-7), 32.9 (C-6), 34.3 (C-3), 37.3 (C4), 60.5 (C-2), 71.6 (C-1). HRMS (ESI-TOF): $[\mathrm{M}+\mathrm{H}]^{+}$ Calcd for $\mathrm{C}_{10} \mathrm{H}_{20} \mathrm{BrO}$ : 235.0697; Found: 235.0681. GCMS (m/z): 236(5), 234(5), 218(2), 216(1), 155(10), 137(71), 110(3), 71(100), 43(81). IR (neat): 2872(s), 2958(s), 3410(broad, s) $\mathrm{cm}^{-1}$.

$[\alpha]_{D}^{20}=-58.7^{\circ}\left(c=0.20, \mathrm{CH}_{3} \mathrm{OH}\right)$.

2.2e 2-Bromo-4- (2-hydroxypropan-2-yl)-1-methylcyclohexanol (5): Compound 5 was prepared from $\alpha$ terpeniol (5 g, $32.89 \mathrm{mmol})$ and NBS (7.03 g, 39.47 $\mathrm{mmol})$ in aqueous acetone $(50 \mathrm{~mL})$. Column chromatographic purification (eluent, 2\% EtOAc in petroleum ether) resulted in white solid, yield 87\% (7.12 g, 28.35 mmol); M.p.: $110-112^{\circ} \mathrm{C}$.

${ }^{1} \mathrm{H}$ NMR $\left(500 \mathrm{MHz}, \mathrm{CDCl}_{3}\right): 1.20\left(\mathrm{~s}, 9-\mathrm{CH}_{3}, 3 \mathrm{H}\right)$, $1.21\left(\mathrm{~s}, 10-\mathrm{CH}_{3}, 3 \mathrm{H}\right), 1.41\left(\mathrm{~s}, 7-\mathrm{CH}_{3}, 3 \mathrm{H}\right), 1.47-1.53$ (m, $\left.0.55-\mathrm{CH}_{2}, 1 \mathrm{H}\right), 1.57-1.67$ (m, 0.5 5- $\mathrm{CH}_{2}, 0.5$ 6$\left.\mathrm{CH}_{2}, 2 \mathrm{H}\right), 1.79-1.87$ (m, 4-CH, $\left.1 \mathrm{H}\right), 1.96$ (dd, , $J=$ 13.90, $4.23 \mathrm{~Hz}, 0.5$ 6- $\left.\mathrm{CH}_{2}, 1 \mathrm{H}\right), 1.99-2.04$ (m, 0.5 3$\mathrm{CH}_{2}, 1 \mathrm{H}$ ), 2.14 (ddd, $J=14.68,12.13,3.19,0.53$ $\left.\mathrm{CH}_{2}, 1 \mathrm{H}\right), 4.21-4.24$ (m, 2-CHBr, $\left.1 \mathrm{H}\right) .{ }^{13} \mathrm{C}$ NMR $\left(125 \mathrm{MHz}, \mathrm{CDCl}_{3}\right): 21.36$ (C-5), 26.94 (C-9), 27.27 (C-10), 29.77 (C-7), 31.16 (C-3), 32.44 (C-6), 41.19 (C-4), 59.72 (C-2), 71.12 (C-1), 72.33 (C-8). HRMS (ESI-TOF): $[\mathrm{M}+\mathrm{H}]^{+}$Calcd for $\mathrm{C}_{10} \mathrm{H}_{20} \mathrm{BrO}_{2}$ : 251.0646; Found: 251.0622. MS (m/z): 234(2), 232(2), 219(5), 217(5), 135(15), 108(20), 95(100), 93(30), 59(60), 43(50). IR (neat): 855(s), 959(s), 1243(s), 2940(s), 2968(s), 3347(b, s) cm ${ }^{-1} \cdot[\alpha]_{D}^{20}=-30.69^{\circ}(c=90.6$, $\left.\mathrm{CH}_{3} \mathrm{OH}\right)$.

\subsection{Synthesis of Carvone (1a) and Compounds $2 \boldsymbol{a}-\mathbf{5 a}$}

In a pear shaped flask $1 \mathrm{~g}$ of substrate (1-5) was taken with $1 \mathrm{~mL}$ DMSO and charged with one equivalent of $\mathrm{ZnS}$. The mixture was stirred under microwave irradiation in an open vessel (Milestone START S microwave laboratory system operated at $70-100^{\circ} \mathrm{C}$, temperature monitored by built-in infrared sensor). The reactions were monitored using worked up aliquot by TLC (5\% EtOAc in hexane) for disappearance of starting material. On completion of reaction, it was poured into water $(20 \mathrm{ml})$ and extracted using $\mathrm{CH}_{2} \mathrm{Cl}_{2}(3 \times 5 \mathrm{~mL})$. The combined organic layer was dried over $\mathrm{Na}_{2} \mathrm{SO}_{4}$ and concentrated to afford crude product. It was purified by column chromatography over silica gel (200-400 mesh) by eluting with mixture of EtOAc and petroleum ether $\left(60-80^{\circ} \mathrm{C}\right)$ to afford pure products $(\mathbf{1 a}, \mathbf{2 a}, \mathbf{3 a}, \mathbf{4 a}$ and 5a).

2.3a 4R-(-)-Carvone (1a): The product was colourless liquid; yield $52 \%$ (336 mg). B.p. $58-60^{\circ} \mathrm{C} / 3.5$ torr. The spectroscopic data were consistent with the standard.

${ }^{1} \mathrm{H}$ NMR (500 MHz, $\mathrm{CDCl}_{3}$ ): 1.77 (s, 10- $\mathrm{CH}_{3}, 3$ $\mathrm{H}), 1.80\left(\mathrm{~m}, 7-\mathrm{CH}_{3}, 3 \mathrm{H}\right), 2.29-2.39\left(\mathrm{~m}, 0.55-\mathrm{CH}_{2}\right.$, $\left.0.53-\mathrm{CH}_{2}, 2 \mathrm{H}\right), 2.43-2.47$ (m, $\left.0.55-\mathrm{CH}_{2} 1 \mathrm{H}\right), 2.58-$ 2.62(m, $\left.0.53-\mathrm{CH}_{2} 1 \mathrm{H}\right), 2.68-2.72(\mathrm{~m}, 4-\mathrm{CH}, 1 \mathrm{H}) 4.77$ (s, $\left.0.59-\mathrm{CH}_{2}, 1 \mathrm{H}\right), 4.82\left(\mathrm{~s}, 0.59-\mathrm{CH}_{2}, 1 \mathrm{H}\right), 6.76-$ $6.78(\mathrm{~m}, 6-\mathrm{CH}, 1 \mathrm{H}),{ }^{13} \mathrm{C} \mathrm{NMR}\left(125 \mathrm{MHz}, \mathrm{CDCl}_{3}\right)$ : 15.3 (C-7), 20.2 (C-10), 30.9 (C-5), 42.2 (C-3), 42.8 (C4), 110.1 (C-9), 135.1 (C-1), 114.2 (C-6), 146.4 (C-8), 
199.4 (C-2). MS ( $m / z): 150(8), 135(4), 122(4), 117(2)$ 108(29), 94 (6), 93 (33), 91 (12), 82 (100), 79 (17), 54 (42), 41 (19). IR (neat): 1675(s), 2923(s), 3082(s) $\mathrm{cm}^{-1}$. $[\alpha]_{\mathrm{D}}^{20}=-47.17^{\circ}\left(c=0.19, \mathrm{CH}_{3} \mathrm{OH}\right)$. HRMS (ESI) $\mathrm{m} / \mathrm{z}:[\mathrm{M}+\mathrm{H}]^{+}$Calculated for $\mathrm{C}_{10} \mathrm{H}_{15} \mathrm{O}, 151.1123$, found 151.1084 .

$2.3 b \quad 2.3 b 4 R-(-)-p-m e n t h-1(6)-e n e-2-o n e$ (2a): The product was colourless liquid; yield $57 \%$ (370 mg). B.p. $43-45^{\circ} \mathrm{C} / 1.5$ torr. ${ }^{1} \mathrm{H}$ NMR $\left(500 \mathrm{MHz}, \mathrm{CDCl}_{3}\right): \delta$ 0.91-0.93 (m, $\left.9 \& 10-\mathrm{CH}_{3}, 6 \mathrm{H}\right), 1.51-158(\mathrm{~m}, 8-\mathrm{CH}$, $1 \mathrm{H}) 1.79\left(\mathrm{~s}, 7-\mathrm{CH}_{3}, 3 \mathrm{H}\right), 2.05-2.07\left(\mathrm{~m}, 0.55-\mathrm{CH}_{2}\right.$, $1 \mathrm{H}), 2.08-2.12$ (m, $\left.0.53-\mathrm{CH}_{2}, 0.55-\mathrm{CH}_{2}, 2 \mathrm{H}\right), 2.51-$ $2.58(\mathrm{~m}, 4-\mathrm{CH}, 1 \mathrm{H}), 2.66-2.70\left(\mathrm{~m}, 0.53-\mathrm{CH}_{2}, 1 \mathrm{H}\right)$, 6.75-6.76 (m, 6-CH, $1 \mathrm{H}) .{ }^{13} \mathrm{C}$ NMR $(125 \mathrm{MHz}$, $\mathrm{CDCl}_{3}$ ): 15.3 (C-7), 19.17 (C-9), 19.21 (C-10), 29.6 (C-5), 31.7 (C-8), 41.67 (C-4), 41.74 (C-3), 135.0 (C-1), 144.9 (C-6), 200.3 (C-2). MS ( $m / z)$ : 153(3), 152(24), 151(3), 124(2), 110(6), 108(6), 96(3), 94(1), 82(100), 79(14), 54(12), 43(3), 41(14). IR (neat): 1666(s), 2874(s), 2959(s), 3020(w) $\mathrm{cm}^{-1} \cdot[\alpha]_{\mathrm{D}}^{20}=$ $-19.6^{\circ}\left(c=0.16, \mathrm{CH}_{3} \mathrm{OH}\right)$. HRMS $(\mathrm{ESI}) \mathrm{m} / \mathrm{z}$ : $[\mathrm{M}+\mathrm{H}]^{+}$Calculated for $\mathrm{C}_{10} \mathrm{H}_{17} \mathrm{O}, 153.1279$, found 153.1295.

2.3c $4 S-(+)-C a r v o n e(3 a)$ : The product was colourless liquid; yield 52\% (336 mg). B.p. $43-45^{\circ} \mathrm{C} / 1.5$ torr. The spectroscopic data were consistent with the standard.

${ }^{1} \mathrm{H}$ NMR (500 MHz, $\left.\mathrm{CDCl}_{3}\right): 1.77\left(\mathrm{~s}, 10-\mathrm{CH}_{3}, 3 \mathrm{H}\right)$, 1.80-1.81 (m, 7- $\left.\mathrm{CH}_{3}, 3 \mathrm{H}\right), 2.27-2.34\left(\mathrm{~m}, 0.55-\mathrm{CH}_{2}, 1\right.$ $\mathrm{H}), 2.36-2.40\left(\mathrm{~m}, 0.53-\mathrm{CH}_{2}, 1 \mathrm{H}\right), 2.43-2.48(\mathrm{~m}, 0.55-$ $\left.\mathrm{CH}_{2}, 1 \mathrm{H}\right), 2.58-2.62\left(\mathrm{~m}, 0.53-\mathrm{CH}_{2}, 1 \mathrm{H}\right), 2.68-2.71(\mathrm{~m}$, 4-CH, $1 \mathrm{H}) 4.77$ (s, $\left.0.59-\mathrm{CH}_{2}, 1 \mathrm{H}\right), 4.82$ (s, $0.59-\mathrm{CH}_{2}$, $1 \mathrm{H}), 6.76-6.78(\mathrm{~m}, 6-\mathrm{CH}, 1 \mathrm{H}) .{ }^{13} \mathrm{C}$ NMR $(125 \mathrm{MHz}$, $\left.\mathrm{CDCl}_{3}\right): \delta 15.7(\mathrm{C}-7), 20.5(\mathrm{C}-10), 31.3(\mathrm{C}-5), 42.5(\mathrm{C}-$ 3), 43.2 (C4), 110.5 (C-9), 135.5 (C-1), 144.6 (C-6), 146.7 (C-8), 199.8 (C-2). MS (m/z): 150(10), 135(5), 122(4), 117(2), 108(29), 94(8), 93(35), 82(100), 79(15), 54(44), 41(20). IR (neat): 1673(s), 2923(s), 3082(s) $\mathrm{cm}^{-1} \cdot[\alpha]_{\mathrm{D}}^{20}=43.12^{\circ}\left(c=0.16, \mathrm{CH}_{3} \mathrm{OH}\right)$. HRMS (ESI) $\mathrm{m} / \mathrm{z}:[\mathrm{M}+\mathrm{H}]^{+}$Calculated for $\mathrm{C}_{10} \mathrm{H}_{15} \mathrm{O}, 151.1123$, found 151.1084 .

2.3d 4S-(+)-p-menth-1(6)-ene-2-one(4a): The product was colourless liquid; yield $40 \%$ (260 mg). B.p. 44$46^{\circ} \mathrm{C} / 1.5$ torr.

${ }^{1} \mathrm{H}$ NMR $\left(500 \mathrm{MHz}, \mathrm{CDCl}_{3}\right): \delta 0.92\left(\mathrm{~s}, 9-\mathrm{CH}_{3}, 3 \mathrm{H}\right)$, 0.93 (s, $\left.10-\mathrm{CH}_{3}, 3 \mathrm{H}\right), 1.56-1.61$ (m, 8-CH, $\left.1 \mathrm{H}\right), 1.78$ (s, 7- $\left.\mathrm{CH}_{3}, 3 \mathrm{H}\right), 1.82-1.90$ (m, 0.5 3- $\left.\mathrm{CH}_{2}, 1 \mathrm{H}\right), 2.09-2.16$ (m, $\left.0.55-\mathrm{CH}_{2}, 4-\mathrm{CH}, 2 \mathrm{H}\right), 2.34-2.40\left(\mathrm{~m}, 0.55-\mathrm{CH}_{2}, 1\right.$ $\mathrm{H}), 2.52-2.57\left(\mathrm{~m}, 0.53-\mathrm{CH}_{2}, 1 \mathrm{H}\right), 6.75-6.76(\mathrm{~m}, 6-\mathrm{CH}$,
$1 \mathrm{H}) .{ }^{13} \mathrm{C} \mathrm{NMR}\left(125 \mathrm{MHz}, \mathrm{CDCl}_{3}\right): \delta 15.3(\mathrm{C}-7), 19.1$ (C-9), 19.5 (C-10), 29.6 (C-5), 31.7 (C-8), 41.6 (C-4), 41.7 (C-3), 135.0 (C-1), 144.9 (C-6), 200.4 (C-2). MS $(\mathrm{m} / \mathrm{z})$ : 153(4), 152(24), 137(5), 135(4), 123(2), 119(3), 110(10), 96(5), 95(16), 82(100), 55(7), 54(20), 43(7), 41(21). IR (neat): 1675(s), 2875(s), 2960(s), 3028(w) $\mathrm{cm}^{-1} \cdot[\alpha]_{\mathrm{D}}^{20}=25.13^{\circ}\left(c=0.125, \mathrm{CH}_{3} \mathrm{OH}\right)$. HRMS (ESI) m/z: $[\mathrm{M}+\mathrm{H}]^{+}$Calculated for $\mathrm{C}_{10} \mathrm{H}_{17} \mathrm{O}, 153.1279$, found 153.1261 .

2.3e 5-(2-hydroxypropan-2-yl)-2-methylcyclohex-2enone (5a): The product was colourless liquid; yield $60 \%$ (400 mg). B.p. $44-46^{\circ} \mathrm{C} / 1.5$ torr.

${ }^{1} \mathrm{H}$ NMR (500 MHz, $\left.\mathrm{CDCl}_{3}\right): 1.21\left(\mathrm{~s}, 9-\mathrm{CH}_{3}, 3 \mathrm{H}\right)$, $1.22\left(\mathrm{~s}, 10-\mathrm{CH}_{3}, 3 \mathrm{H}\right), 1.75-1.78\left(\mathrm{~m}, 7-\mathrm{CH}_{3}, 3 \mathrm{H}\right), 2.04-$ 2.08(m, $\left.0.54-\mathrm{CH}_{2}, 1 \mathrm{H}\right), 2.20-2.27\left(\mathrm{~m}, 0.54-\mathrm{CH}_{2}, 0.5\right.$ 5- $\left.\mathrm{CH}_{2}, 2 \mathrm{H}\right), 2.40-2.48$ (m, $\left.0.56-\mathrm{CH}_{2}, 1 \mathrm{H}\right), 2.60$ (dq, $\left.J=15.87,1.75,0.56-\mathrm{CH}_{2}, 1 \mathrm{H}\right), 6.74-6.78(\mathrm{~m}, 0.53-$ $\mathrm{CH}, 1 \mathrm{H}),{ }^{13} \mathrm{C}$ NMR $\left(125 \mathrm{MHz}, \mathrm{CDCl}_{3}\right): 15.2(\mathrm{C}-7)$, 26.7 (C-5), 26.9 (C-9), 26.9 (C-10), 39.30 (C-6), 45.7 (C-5), 71.1 (C-8), 134.8 (C-2), 144.9 (C-3), 200.0 (C-1). MS $(m / z)$ : 153(1), 150(20), 135(15), 110(70), 109(40), 95(60), 82(20), 59(100), 43(20). IR (neat): 1707(m), 2930(s), 2967(s), 3325(b, m) cm $\mathrm{cm}^{-1} \cdot[\alpha]_{\mathrm{D}}^{20}=$ $53.48^{\circ}\left(c=0.20, \mathrm{CH}_{3} \mathrm{OH}\right)$. HRMS (ESI) m/z: $[\mathrm{M}+\mathrm{H}]^{+}$ Calculated for $\mathrm{C}_{10} \mathrm{H}_{17} \mathrm{O}_{2}, 169.1228$, found 169.1210 .

\section{Results and Discussion}

In the beginning, oxidation of 2-bromo-1-hydroxy- $p$ menth-8-ene (1, scheme 1) using $\mathrm{ZnS}$ and DMSO was taken up. We observed the formation of 2,3-unsaturated ketone (1a) as a major product by dehydrationoxidation process. This observation is new and product 1a is an important flavour compound. It was also found that the amount of DMSO used in the reaction was not a critical factor, since 1a was formed to an equal extent in either DMSO as a solvent or as an oxidant in 1:1 ratio with the substrate. Hence, a new green procedure for the synthesis of the flavour compound was identified. The scope of this green procedure was demonstrated with substrates $\mathbf{2 - \mathbf { 5 }}$ as well. The results are summarized in table 1.

Microwave Assisted Dehydration and Oxidation (MADO) of $\mathbf{1}$ in presence of $\mathrm{ZnS} / \mathrm{DMSO}$ resulted in the isolation of 1a (carvone) as a major product. This was checked and confirmed by TLC and GC analyses with standard carvone. The specific optical rotation of this compound was $[\alpha]=-47.17^{\circ}$, confirming it to be $4 R$ (-)-carvone. The substrate $\mathbf{1}$ is sensitive to both Lewis acid and base to give respectively 2-bromo-1,8-cineole and trans-limonene oxide. ${ }^{11}$ Noticeably, under MADO, 
Table 1. MADO of $\beta$-bromo-tert-alcohols in ZnS/DMSO.

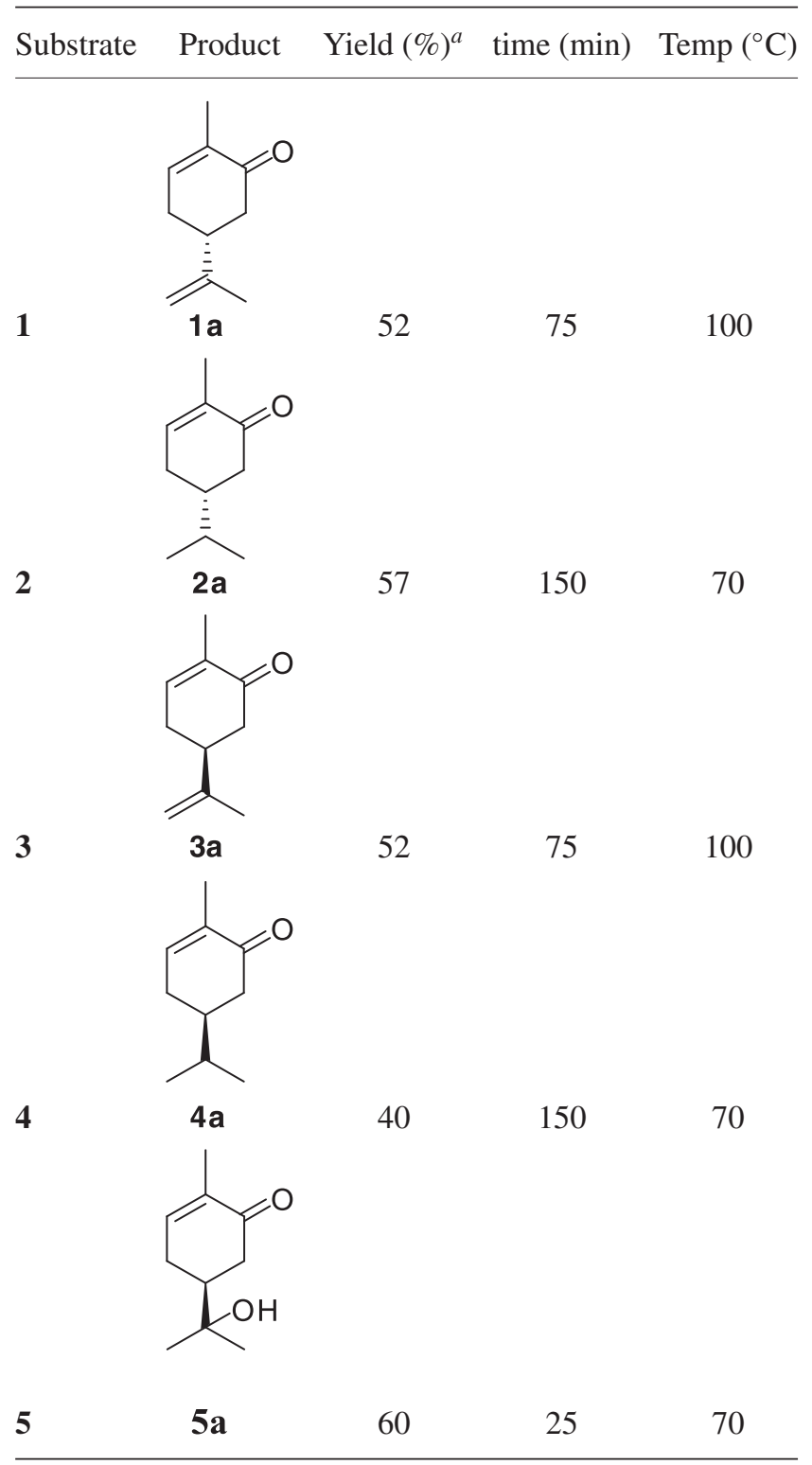

$a^{a}$ isolated yield

it afforded carvone. MADO of $\mathbf{2}$ afforded 2a in $57 \%$ isolated yield. In case of (4S)-2-bromo-1-hydroxy$p$-menth-8-ene (3), the reaction was completed in 75 min and product (3a) was obtained in 52\% yield. 2-Bromo-1-hydroxy- $p$-menthane (4) yielded $40 \%$ of
MADO product (4a). Similarly, MADO of 2-bromo4-(2-hydroxypropan-2-yl)-1-methylcyclohexanol (5) produced 60\% 5-(2-hydroxypropan-2-yl)-2-methylcyclohex-2-enone (5a) in $25 \mathrm{~min}$. Interestingly, the dehydration of hydroxyl at position 8 in $\mathbf{5}$ was not observed. Hence, we got interested to study the role of vicinal bromo group in $\beta$-bromo-tert-alcohols, such as $\mathbf{1}$, for elimination of hydroxyl group.

To explain the mechanism, a test reaction was conducted in DMSO with the system (1b) devoid of vicinal bromide under microwave at $100^{\circ} \mathrm{C}$. Two test conditions were adopted, one in the presence of $\mathrm{ZnS}$ and another in its absence. Under both the conditions, the substrate was recovered as such without any reaction $(2 \mathrm{~h})$. Hence, for dehydration to occur in $\beta$-bromo-tert-alcohols, presence of vicinal bromide was a prerequisite. Also, we found the presence of vicinal-hydroxyl to the bromide facilitates its oxidation to carbonyl group. It was checked by replacing hydroxyl with methoxy in 1 . The MADO reaction did not proceed even at $100^{\circ} \mathrm{C}$ for $2 \mathrm{~h}$ and substrate was recovered as such. From these results the role of $\mathrm{ZnS}$ in facilitating the dehydration and oxidation is evident. Hence, we envisage a concerted bi-functional activation of hydroxyl and bromide under microwave by $\mathrm{ZnS}$ (scheme 2, 1d). The intermediate 1d undergoes Kornblum oxidation leading to generation of carbonyl functionality and also eliminates a molecule of water resulting in the formation of 2,3-unsaturated ketone.

The dual transformation displayed by $\beta$-bromo-tertalcohols under microwave was very interesting. In order to extend the scope of the reaction using different metal salts as promoters for MADO, reaction of $\mathbf{1}$ was carried out in presence of metal salts like $\mathrm{AgNO}_{3}, \mathrm{Fe}_{2} \mathrm{SO}_{4}$, $\mathrm{CuSO}_{4}, \mathrm{Zn}(\mathrm{OAc})_{2}, \mathrm{Li}_{2} \mathrm{SO}_{4}$, and $\mathrm{NaNO}_{2}$. The results are summarised in table 2. It was observed that, three types of oxidation products were formed. The major product was found to be 2,3-unsaturated ketone (1a, entry 1 and 6). The minor products were rearranged ketone (1c) and hydroxy ketone (1b) similar to earlier report. ${ }^{9}$ It was also revealed from study that the important factor influencing reaction towards formation of $\mathbf{1 a}, \mathbf{1 b}$

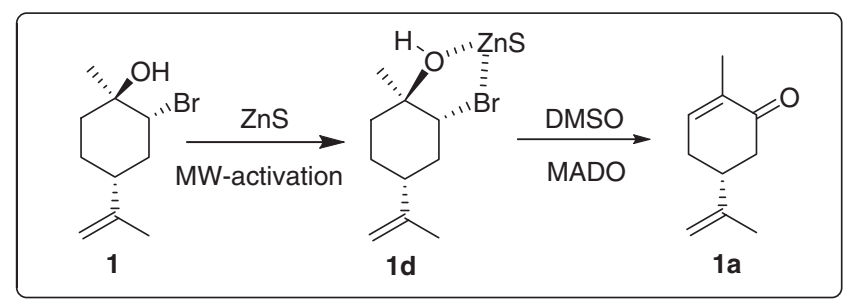

Scheme 2. Plausible bi-functional activation of $\beta$-bromo-tert-alcohols. 
Table 2. Microwave-assisted oxidation of 2-bromo-1-hydroxy- $p$-menthan-8-ene in $\mathrm{DMSO} / \mathrm{metal}$ salts.

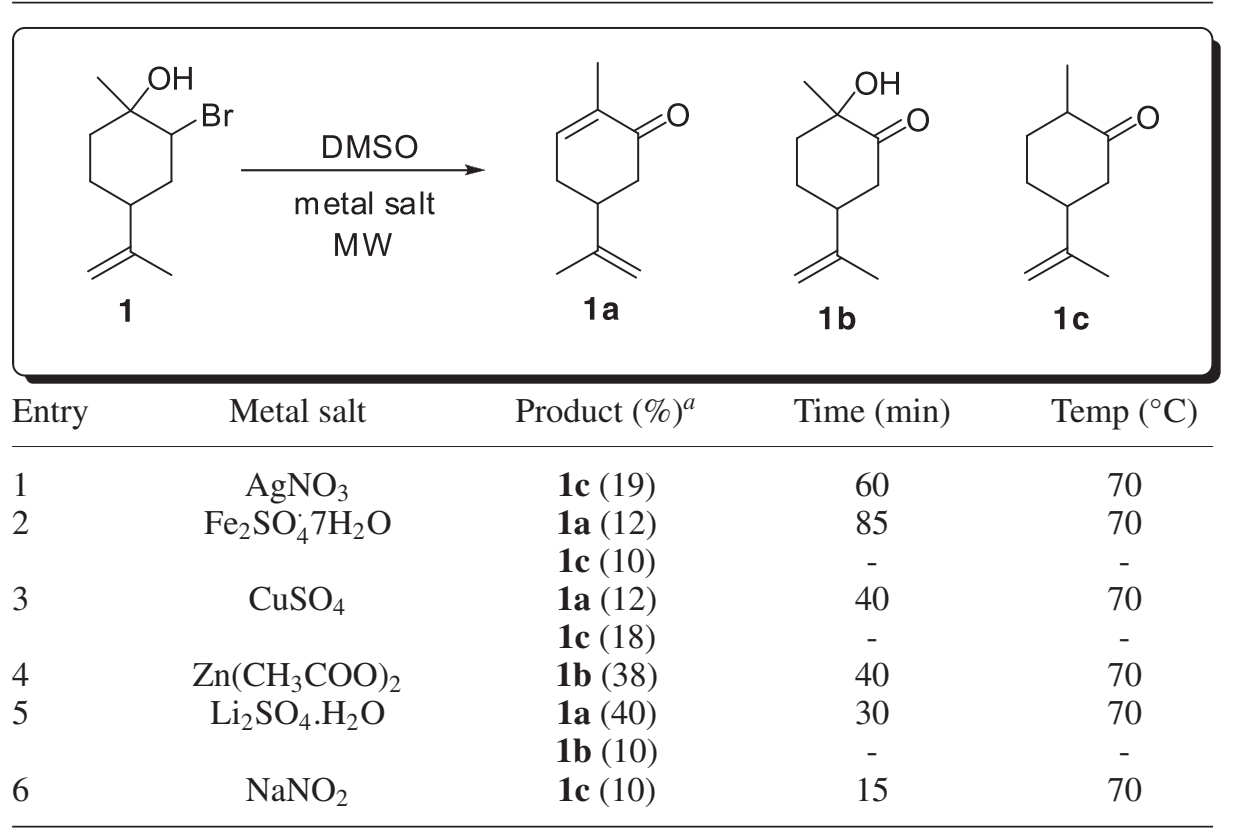

${ }^{a}$ : Isolated yield

and 1c is the choice of the metal salt. The formation of $1 \mathbf{a}$ was the major product in the presence of $\mathrm{ZnS}$ whereas 1c was the major product with $\mathrm{Zn}(\mathrm{OAc})_{2}$. In the presence of $\mathrm{Li}_{2} \mathrm{SO}_{4}$, the reaction was competitive for the formation of $\mathbf{1 a}$ and $\mathbf{1 b}$. With salts like $\mathrm{NaNO}_{2}$, $\mathrm{CuSO}_{4}, \mathrm{Fe}_{2} \mathrm{SO}_{4}$ and $\mathrm{AgNO}_{3}$, mixture of compounds were detected. Hence using $\mathrm{ZnS}$, the conversion of $\beta$ bromo-tert-alcohols to important flavour compounds was achieved.

\section{Conclusions}

In conclusion, we report a new microwave-assisted, one-pot direct dehydration-oxidation of $\beta$-bromo-tertalcohols to flavour compounds. The metal salts used for the reactions are inexpensive and easily available. Reactions are carried out in the absence of solvent and generally applicabile to $\beta$-bromo-tert-alcohols derived from 1,4-disubstitued-1-cyclohexenes.

\section{Supplementary Information}

The electronic supplementary material contains GCMS, FT-IR, ${ }^{1} \mathrm{H}$ NMR, ${ }^{13} \mathrm{C}$ NMR and HR-MS data for compounds 3, 4, 5, 1a, 2a, 3a, 4a and 5a, which can be seen at www.ias.as.in/chemsci.

\section{Acknowledgements}

$\mathrm{KN}$ is grateful to the Department of Science and Technology, New Delhi, India for the award of INSPIRE fellowship. Dr. P. Srinivas, Chief Scientist, CSIR-CFTRI is acknowledged for his valuable suggestions. Authors are thankful to Mr. Shivaswamy, CFTRI, Mysore, for GC-MS analysis.

\section{References}

1. Lidstrom P, Tierney J, Wathey B and Westman J 2001 Tetrahedron $\mathbf{5 7} 9225$

2. Kappe C O 2004 Angew. Chem. Int. Ed. 436250

3. Perreux L and Loupy A 2001 Tetrahedron 579199

4. Varma R S and Ju Y 2006 In Microwaves in organic synthesis A Loupy (Ed.) (Weinheim: Wiley-VCH)

5. Rodriguez J and Dulcere J 1993 Synthesis 1177

6. Piva O 1992 Tetrahedron Lett 332459

7. Dolenc D and Harej M 2002 J. Org. Chem. 67312

8. Rekha S, Prabhat G, Shaikh M M and Rajneesh M 2013 Dalton Trans 425539

9. Bettadaiah B K, Guruduttm K N and Srinivas P $2003 \mathrm{~J}$. Org. Chem 682460

10. Bettadaiah B K and Srinivas P 2003 Synth. Commun. 33 3615

11. Gurudutt K N, Rao S and Srinivas P 1992 Flav. Fragr. J. 7343 